\title{
Susceptibility to Febrile Seizures: More Than Just a Faulty Thermostat!
}

\author{
Asuri N. Prasad, Shashi S. Seshia
}

Can. J. Neurol. Sci. 2009; 36: 277-279

A febrile seizure is generally defined for epidemiological purposes as 'an event' (i.e. a seizure) in infancy or childhood usually occurring between three months and five years of age associated with a fever, but without evidence of intracranial infection or defined cause. ${ }^{1}$ With an incidence of about $5 \%,{ }^{2}$ possibly higher in some countries like Japan, febrile seizures are common in pediatric practice.

\section{COMMENTS ON THE PAPER OF GORDON ET AL ${ }^{3}$}

In the March 2009 issue of the Journal, in a paper titled 'Is temperature regulation different in children susceptible to febrile seizures?,' Gordon et al explored the relationship between "the presence and magnitude of fever and susceptibility to febrile seizures, defined as a known family history of febrile seizures."3 They did not explain why they elected to re-analyze information collected between 1989 and 1991, ${ }^{4}$ instead of performing a more current study designed to address their objectives. They concluded their data supported the speculation of Rantala et $\mathrm{al}^{5}$ that "regulation of temperature is different in children susceptible to febrile seizures"; 'regulation of temperature' was not defined in either paper. We suggest evidence has not been provided to support their conclusion. We also have reservations with the assumption that a family history of febrile seizures is an unqualified marker for susceptibility to febrile seizures.

Gordon et $\mathrm{al}^{3}$ drew attention to the biases in their study. These will not be discussed with the exception of one: the measurement of temperature, the key variable in reports such as theirs. A variety of factors, especially inter- and intra-observer variability in measurement and the method used for recording, influence temperature data. These were not addressed.

Their paper is a stimulus to briefly review the factors that may contribute to febrile seizure susceptibility.

\section{FEVER, DEVELOPMENTAL MATURATION AND FEBRILE SEIZURES}

The clinically observed association between fever and the age-dependent vulnerability to febrile seizures is implicit in the definition. The peak body temperature is an important variable. ${ }^{6}$ Millichap opined that "seizures occurred when the degree of fever reached or surpassed the threshold convulsive temperature for each individual patient" (emphasis ours). He suggested that the factors determining this threshold were likely inherited. Experimentally too, there is an age-dependent vulnerability, ${ }^{7-11}$ although the responsible factors have to be explicitly identified.

\section{IS THE CAUSATIVE AGENT OF FEVER IMPORTANT?}

Millichap postulated that the source of fever could contribute independently to febrile seizures. ${ }^{6}$ Until recently, the infective agent has not generally been considered relevant for susceptibility. Now, information suggests that some viruses such as human herpesvirus- 6 may have a more than chance association with febrile seizures, especially recurrent. ${ }^{7}$ Therefore, Millichap's suggestion ${ }^{6}$ needs to be investigated with renewed vigor, factoring in possible geographic differences.

\section{NEUROBIOLOGICAL CHANGES ASSOCIATED WITH FEVER}

The neurobiological changes that occur during experimentally induced hyperthermia are different from those that occur during illness related fever. ${ }^{10}$ The pyrogenic response to an inflammatory stimulus is the result of a complex series of interactions between neural, endocrine and immune systems. ${ }^{12}$ Prostaglandins and endogenous cytokines involved in central and peripheral mechanisms responsible for the febrile reaction may have a role in causing febrile seizures. ${ }^{13-15}$ Genes coding for proteins and signaling molecules involved in thermoregulation may influence the degree and height of fever, the individual threshold for and susceptibility to febrile seizures. Evidence to support such speculation is needed.

Schuchmann et al have suggested that hyperthermia causes tachypnea which results in respiratory alkalosis in the immature brain. ${ }^{16}$ The resultant rise in brain $\mathrm{pH}$ enhances neuronal excitability and produces febrile seizures. The authors suggested that alterations in the $\mathrm{pH}$ sensitivity of mutated channels associated with well characterized epilepsy syndromes (see below) provide a potential mechanism for susceptibility in these conditions; in addition, genes coding for proteins involved in the control of respiration, could provide other candidate modifier or susceptibility genes. ${ }^{16}$

Potentially, there could be many 'needles' in the 'thermoregulatory haystack', contributing to susceptibility.

\section{OTHER SYSTEMIC FACTORS}

The issue of iron deficiency (a common early childhood problem) and susceptibility to febrile seizures ${ }^{17}$ needs further

From Pediatrics \& Clinical Neurosciences, Dept. of Pediatrics (ANP), Schulich Medicine \& Dentistry, Children's Hospital at London Health Sciences Centre, London, Ontario; Department of Pediatrics (SSS), Royal University Hospital, University of Saskatchewan, Saskatoon, Saskatchewan, Canada.

Received February 3, 2009. Final Revisions Submitted February 9, 2009. Correspondence to: Shashi S. Seshia, 10 Stockton Place, Winnipeg, Manitoba, R3P 1X2, Canada. 
study clinically and experimentally. Other under-explored areas include biochemical and metabolic abnormalities in patients with febrile seizures, particularly recurrent.

\section{GENETIC INFLUENCES}

The incidence of febrile seizures in $1^{\text {st }}$ degree relatives of children presenting with Febrile seizures (FSs) ranges from at least 9\%-22\%.,18-20 There is a higher concordance rate in monozygotic than dizygotic twins. ${ }^{18,21,22}$ Males are more susceptible than females, surely another area for further investigation.

At least six susceptibility loci have been mapped, although the causative genes have not been identified in most patients: FEB1 (8q13-q21), FEB2 (19p13), FEB3 (2q23-q24), FEB4 (5q14-q15), FEB5 (6q22-q24), and FEB6 (18p11). ${ }^{23}$ The FEB4 locus may account for $70 \%$ of commonly encountered febrile seizure susceptibility.

Over the past decade, families with Mendelian inheritance patterns and single gene defects have been described with distinct genotype phenotype correlations. Febrile seizures, often recurring, are key features in these cases. These syndromes include: (i) generalized epilepsy febrile seizures plus (GEFS+) ${ }^{24-}$ ${ }^{28}$ and (ii) Dravet syndrome. ${ }^{29,30}$ Ceulemans et al suggest that the clinical spectrum of SCN1A gene mutations ranges from simple febrile seizures to Dravet syndrome. ${ }^{30}$ Currently, such syndromes are considered to explain only a minority of those with febrile seizures; the majority are genetically heterogeneous and of complex inheritance. Advances in population genetics studies, pooling of genetic data and the availability of haplotype mapping, should lead to identification of other susceptibility loci and modifier genes associated with febrile seizures. The study of the relative contributions of genetic variants in the coding and non coding regions of the human genome (known and unknown mutations, polymorphisms of pathogenic significance) and epigenetic factors in individuals and families with febrile seizures may provide additional clues.

Kang et al showed temperature dependent trafficking and/or accelerated endocytosis of heterozygous mutant $\alpha 1 \beta 2 \gamma 2$ receptors containing $\gamma 2$ subunit mutations associated with febrile seizures. ${ }^{31}$ They suggest that febrile seizures may be produced by a temperature-induced dynamic reduction in the expression and recycling of mutant surface $\mathrm{GABA}_{\mathrm{A}}$ receptors in response to fever. Thus, molecular genetics is helping to not only define the clinical spectrum of febrile seizures and febrile seizure+ syndromes but is also providing insights into possible mechanisms determining susceptibility.

The report of sudden unexpected death in two members of a family who had GEFS+ with an SCN1A mutation suggests a possible association between channelopathies affecting brain and heart in families with comparable mutations. ${ }^{32}$ We speculate that gene defects could underlie the increased risk of death in (some of) those with complex febrile seizures. ${ }^{33}$ Yet another aspect for investigation.

\section{NEURONAL MIGRATION DISORDERS AND EARLY ACQUIRED LESIONS}

In 1976, Wallace suggested that preexisting developmental defects could predispose to febrile seizures, ${ }^{34}$ an opinion now supported experimentally and neuroradiologically. ${ }^{35-37}$ Strictly, these experimental models and cases would not meet the clinical criterion for febrile seizures, as there is an underlying symptomatic cause. Nevertheless, these studies have clinical relevance, especially for complex and recurrent febrile seizures, as dysgenesis may need to be looked for diligently and microdysgenesis may only be detected by pathological examination. These issues exemplify the challenges of differentiating between idiopathic, symptomatic and cryptogenic causes for seizures, one of the areas currently being tackled by the Commission on Classification and Terminology of the International League against Epilepsy (ILAE) ${ }^{38}$

\section{SUMMARY}

Febrile seizures, always a hot topic, continue to fire up the interest of a wide spectrum of clinical and basic neuroscientists. Several clinical investigators, amongst them the Halifax group (spearheaded by the Camfields to whom we owe a great debt of gratitude for their contributions in this field), have provided us with a sound foundation for clinical management. We now need to explore febrile seizures in new ways to clarify factors and identify mechanisms that contribute to the intriguing agedependent susceptibility. The complex processes involved in thermoregulation and the febrile response are important pieces of the puzzle. The contributory factors are likely different for isolated simple febrile, recurrent febrile and complex febrile seizures. A 'systems biology approach' is needed to investigate the intricate genome-proteome-metabolome interaction in determining susceptibility. Population studies that incorporate current clinical, experimental, infectious and molecular genetic knowledge in their concept and design will help to 'conquer' the final frontiers of febrile seizures. In 2006, Engel suggested that febrile seizures could 'encompass many different entities', ${ }^{39}$ an increasingly plausible opinion. A higher profile for febrile seizures and related syndromes in the ILAE classification scheme will further catalyze progress in the field. The resultant knowledge can only improve management.

\section{ACKNOWLEDGEMENTS}

The authors thank Professor Victor Chernick (University of Manitoba) for invaluable discussion and Mr. Jamie Seabrook (Child Health Research Institute, London, Ontario) for statistical expertise.

\section{REFERENCES}

1. Consensus statement. febrile seizures: Long-term management of children with fever-associated seizures. Pediatrics. 1980;66(6): 1009-12.

2. Nelson KB, Ellenberg JH. Prognosis in children with febrile seizures. Pediatrics. 1978;61(5):720-7.

3. Gordon KE, Dooley JM, Wood EP, Bethune P. Is temperature regulation different in children susceptible to febrile seizures? Can J Neurol Sci. 2009;36:192-5.

4. Bethune P, Gordon K, Dooley J, Camfield C, Camfield P. Which child will have a febrile seizure? Am J Dis Child. 1993;147(1): 35-9.

5. Rantala H, Uhari M, Hietala J. Factors triggering the first febrile seizure. Acta Paediatr. 1995;84(4):407-10.

6. Millichap JG. Studies in febrile seizures. I. height of body temperature as a measure of the febrile-seizure threshold. Pediatrics. 1959;23(1 Part 1):76-85. 
7. Millichap JG, Millichap JJ. Role of viral infections in the etiology of febrile seizures. Pediatr Neurol. 2006;35(3):165-72.

8. Lennox MA, Sibley WA, Zimmerman HM. Fever and febrile convulsions in kittens: a clinical, electroencephalographic, and histopathologic study. J Pediatr. 1954;45(2):179-90.

9. Holtzman D, Obana K, Olson J. Hyperthermia-induced seizures in the rat pup: A model for febrile convulsions in children. Science. 1981;213(4511):1034-6.

10. McCaughran JA,Jr, Schechter N. Experimental febrile convulsions: long-term effects of hyperthermia-induced convulsions in the developing rat. Epilepsia. 1982;23(2):173-83.

11. Liebregts MT, McLachlan RS, Leung LS. Hyperthermia induces age-dependent changes in rat hippocampal excitability. Ann Neurol. 2002;52(3):318-26.

12. Elmquist JK, Scammell TE, Saper CB. Mechanisms of CNS response to systemic immune challenge: the febrile response. Trends Neurosci. 1997;20(12):565-70.

13. Rantala H, Tarkka R, Uhari M. Systematic review of the role of prostaglandins and their synthetase inhibitors with respect to febrile seizures. Epilepsy Res. 2001:46(3):251-7.

14. Masuyama $\mathrm{T}$, Matsuo $\mathrm{M}$, Ichimaru $\mathrm{T}$, Ishii $\mathrm{K}$, Tsuchiya $\mathrm{K}$, Hamasaki Y. Possible contribution of interferon-alpha to febrile seizures in influenza. Pediatr Neurol. 2002; 27(4):289-92.

15. Vezzani A, Baram TZ. New roles for interleukin-1 beta in the mechanisms of epilepsy. Epilepsy Curr. 2007;7(2):45-50.

16. Schuchmann S, Schmitz D, Rivera C, Vanhatalo S, Salmen B, Mackie K, et al. Experimental febrile seizures are precipitated by a hyperthermia-induced respiratory alkalosis. Nat Med. 2006; 12(7):817-23

17. Daoud AS, Batieha A, Abu-Ekteish F, Gharaibeh N, Ajlouni S, Hijazi S. Iron status: a possible risk factor for the first febrile seizure. Epilepsia. 2002;43(7):740-3.

18. Lennox-Buchthal MA. Febrile convulsions. A reappraisal. Electroencephalogr Clin Neurophysiol. 1973;32 Suppl:1-138.

19. Berg AT, Shinnar S, Hauser WA, Alemani M, Shapiro ED, Salomon $\mathrm{ME}$, et al. A prospective study of recurrent febrile seizures. $\mathrm{N}$ Engl J Med. 1992;327(16):1122-7.

20. Waruiru C, Appleton R. Febrile seizures: an update. Arch Dis Child. 2004;89(8):751-6.

21. Corey LA, Berg K, Pellock JM, Solaas MH, Nance WE, DeLorenzo RJ. The occurrence of epilepsy and febrile seizures in Virginian and Norwegian twins. Neurology. 1991;41(9):1433-6.

22. Kjeldsen MJ, Kyvik KO, Friis ML, Christensen K. Genetic and environmental factors in febrile seizures: a Danish populationbased twin study. Epilepsy Res. 2002;51(1-2):167-77.

23. Nakayama J, Arinami T. Molecular genetics of febrile seizures. Epilepsy Res. 2006;70 Suppl 1:S190-8.

24. Escayg A, Heils A, MacDonald BT, Haug K, Sander T, Meisler MH. A novel SCN1A mutation associated with generalized epilepsy with febrile seizures plus--and prevalence of variants in patients with epilepsy. Am J Hum Genet. 2001;68(4):866-73.

25. Harkin LA, Bowser DN, Dibbens LM, Singh R, Phillips F, Wallace $\mathrm{RH}$, et al. Truncation of the $\operatorname{GABA}(\mathrm{A})$-receptor gamma2 subunit in a family with generalized epilepsy with febrile seizures plus. Am J Hum Genet. 2002;70(2):530-6.
26. Baulac S, Gourfinkel-An I, Nabbout R, Huberfeld G, Serratosa J, Leguern E, et al. Fever, genes, and epilepsy. Lancet Neurol. 2004:3(7):421-30.

27. Baulac S, Gourfinkel-An I, Couarch P, Depienne C, Kaminska A, Dulac O, et al. A novel locus for generalized epilepsy with febrile seizures plus in french families. Arch Neurol. 2008;65(7): 943-51.

28. Sun H, Zhang Y, Liang J. Liu , Ma X, Wu H, et al. SCN1A, SCN1B, and GABRG2 gene mutation analysis in Chinese families with generalized epilepsy with febrile seizures plus. J Hum Genet. 2008;53(8):769-74.

29. Nabbout R, Gennaro E, Dalla Bernardina B, Dulac O, Madia F, Bertini E, et al. Spectrum of SCN1A mutations in severe myoclonic epilepsy of infancy. Neurology. 2003;60(12):1961-7.

30. Ceulemans BP, Claes LR, Lagae LG. Clinical correlations of mutations in the SCN1A gene: from febrile seizures to severe myoclonic epilepsy in infancy. Pediatr Neurol. 2004;30(4): 236-43.

31. Kang JQ, Shen W, Macdonald RL. Why does fever trigger febrile seizures? GABAA receptor gamma2 subunit mutations associated with idiopathic generalized epilepsies have temperature-dependent trafficking deficiencies. J Neurosci. 2006;26(9):2590-7.

32. Hindocha N, Nashef L, Elmslie F , Birch R, Zuberi S, Al-Chalabi A, et al. Two cases of sudden unexpected death in epilepsy in a GEFS+ family with an SCN1A mutation. Epilepsia. 2008;49(2): 360-5.

33. Mazumdar M. Febrile seizures and risk of death. Lancet. 2008;372 (9637):429-30

34. Wallace S. Neurological and intellectual deficits: convulsions with fever viewed as acute indications of life-long developmental defects. In: Brazier MAB, Coceani F, editors. Brain dysfunction in infantile febrile convulsions. New York: Raven Press; 1976. p. 259-77.

35. Germano IM, Zhang YF, Sperber EF, Moshé SL. Neuronal migration disorders increase susceptibility to hyperthermiainduced seizures in developing rats. Epilepsia. 1996;37(9): 902-10.

36. Scantlebury MH, Ouellet PL, Psarropoulou C, Carmant L. Freeze lesion-induced focal cortical dysplasia predisposes to atypical hyperthermic seizures in the immature rat. Epilepsia. 2004;45 (6):592-600 .

37. Hesdorffer DC, Chan S, Tian H, Hauser AW, Dayan P, Leary LD, et al. Are MRI-detected brain abnormalities associated with febrile seizure type? Epilepsia. 2008;49(5):765-71.

38. Commission on Classification and Terminology. International League Against Epilepsy. Available from: http://www.ilae.org/ Visitors/Centre/ctf/ctfoverview.cfm. [Cited 2009 Jan 23].

39. Engel J,Jr. Report of the ILAE classification core group. Epilepsia. 2006;47(9):1558-68. 